\title{
Peranan Aplikasi Android Dalam Peningkatan Kualitas Pelayanan Sekolah di Pesantren Persis Kota Tasikmalaya
}

\author{
Fadhlillah \\ Sekolah Pascasarjana Universitas Islam “45” Bekasi \\ fadilfadhlillah1@gmail.com \\ Aos Kuswandi \\ Sekolah Pascasarjana Universitas Islam “45” Bekasi \\ aos_kuswandi@unismabekasi.ac.id \\ Pauzan Haryono \\ Sekolah Pascasarjana Universitas Islam ‘45’ Bekasi \\ pauzanharyono@gmail.com
}

\begin{abstract}
The goals of this research are 1) to find out school services that are implemented in Pesantren PERSIS Benda Kota Tasikmalaya, 2) to get an overview of the android application used in pesantren PERSIS Benda Kota Tasikmalaya. 3) to measure the role of "67Benda" android applications in improving school services to student's parents. This research is a qualitative research that produces data in the form of descriptions. Data collection methods using observation, interviews ang document study. The results shows that pesantren PERSIS Benda Kota Tasikmalaya gradually improve the quality of ducation because the role of the '67Benda" android application that has been implemented. It has been running well even thought the system and service need to be improved. There are some things are needed to support the use of this application such as, the qualified and adequate operators, a proper infrastructure, and the support also enthusiasm from teachers and parents. Factors that may hinder the use of "67Benda" are: (1) unskilled human resources in managing the application, (2) the incomplete application, and (3) signal interference. The role of the implementation "67Benda" android application has shown a very significant outcome to school services. It can be seen that the information is easier to be obtained by the student's parents.
\end{abstract}

Keywords: Android Application, School Service, Boarding School

\section{Article Info}

Received date: 2 November $2020 \quad$ Revised date: 10 Februari $2021 \quad$ Accepted date: 21 Juni 2021

\section{PENDAHULUAN}

Perkembangan teknologi informasi dan komunikasi telah melahirkan model pelayanan pendidikan yang dilakukan melalui aplikasi dan web browser. Pelayanan manual bisa diganti dengan pemanfaatan aplikasi sehingga lebih fleksibel dan lebih berorientasi pada kepuasan pengguna dan peningkatan kualitas pendidikan (Rusdiana, 2015). Saat ini teknologi informasi telah banyak dimanfaatkan untuk pengolahan data karena memiliki banyak kelebihan diantaranya kecepatan, keakuratan serta 
efisiensi dibandingkan dengan sistem manual. Perkembangan teknologi yang saat ini sedang mengalami kemajuan yang sangat pesat adalah teknologi mobile terutama untuk smartphone Android (Hariyanto, 2019). Tidak dapat disangkal perkembangan aplikasi pada smartphone khususnya aplikasi android merupakan salah satu hal terpenting yang diterapkan untuk membuka cakrawala dengan membuat dan menerapan penggunaan aplikasi dalam sebuah institusi ataupun perusahaan ( $\mathrm{Al}$ Rekhawi, 2020)

Konsep aplikasi merupakan suatu program yang siap untuk digunakan yang dibuat untuk melaksanakan suatu fungsi bagi pengguna jasa aplikasi serta penggunaan aplikasi lain yang dapat digunakan oleh suatu sasaran yang akan dituju (Juansyah, 2015). Aplikasi saat ini memainkan peran yang sangat penting dalam kehidupan sehari-hari (Xiao, J.; Chen, S.; He, Q.; Feng, 2020). Aplikasi ini sering dikenal dalam program handphone berbasis android.

Android menurut Kuswanto adalah sebuah sistem operasi untuk smartphone dan tablet (Kuswanto, 2018) Dalam pandangan lain android merupakan sistem operasi untuk perangkat mobile berbasis linux yang mencakup sistem operasi, middleware dan aplikasi (Komputer, 2013). Lebih Jauh dijelaskan oleh Putra dan Nugroho bahwa android merupakan sistem operasi open source, artinya gratis dan bebas digunakan oleh siapapun dan memudahkan para developer untuk mengembangkan aplikasi (Putra, 2016). Berdasarkan pendapat tersebut dapat dipahami bahwa android adalah suatu sistem operasinal bersifat open source yang dikhususkan untuk perangkat mobile.

Aplikasi dalam android inilah yang dalam perkembangan teknologi komunikasi banyak digunakan untuk kemudahan dalam komunikasi manusia, baik sebagai individu, kelompok maupun lembaga. Ini merupakan aplikasi yang memudahkan dalam penerapan sistem informasi. Salah satu cara mengukur kualitas sistem informasi menurut Mustakini dalam (Mustakini, 2007) dengan menggunakan pengukuran -pengukuran sebagai berikut : 1) Respone time (waktu respon), 2) Data accuracy (akurasi data), 3) Proposed data currency (kekinian data yang diusulkan), 4) Completeness (kelengkapan), Realibility (keandalan), 5) Ease of use (kemudahan penggunaan)

Kualitas pelayanan jasa adalah tingkat keunggulan yang diharapkan dapan memenuhi keinginan pelanggan, apabila pelayanan yang diterima (perceived service) selaras dengan harapan pelanggan (expected service), maka kualitas pelayanan yang telah diberikan dapat dikatakan baik (Hutagalung, 2019). Kualitas pelayanan dalam sebuah sistem informasi dapat mendukung berjalannya pelayanan lembaga maupun organisasi. Demikian juga halnya pada lembaga pendidikan. Baik pendidikan formal maupun non formal.

Pelayanan informasi dan administrasi pada lembaga pendidikan, saat ini banyak menggunakan berbagai aplikasi android. Salah satunya dalah di pesantren PERSIS 67 Benda kota Tasikmalaya, yang menjadi obyek penelitian ini. Pada lembaga ini pada awalnya masih menggunakan sistem manual. Dalam perjalananya, sistem manual tersebut dikhawatirkan membuat data yang tersimpan pada perangkat komputer menjadi riskan atau hilang. Pada sisi lain, sistem manual membuat wali santri (wali murid) mendapatkan pelayanan informasi dan administrasi menjadi lebih lama karena jarang bertemu langsung dengan anaknya atau dengan wali kelasnya. Kondisi inilah yang menjadikan perlunya perubahan paradigma pelayanan sekolah kepada orangtua murid. Pilihannya adalah menggunakan teknologi komunikasi berbasis aplikasi android.

Lembaga berusaha untuk mengikuti perkembangan zaman yang begitu cepat dalam rangka memberi kemudahan dan mempercepat 
akses informasi, khususnya bagi wali santri. Upaya peningkatan kualitas pelayanan dilakukan melalui menerapkan pelayanan pendidikan berbasis Android. Program ini disebut dengan aplikasi android "67Benda". Aplikasi ini merupakan aplikasi berbasis Mobile yang dapat didownload di play store dan diakses melalui jaringan internet.Berikut Gambar aplikasi android "67 Benda":

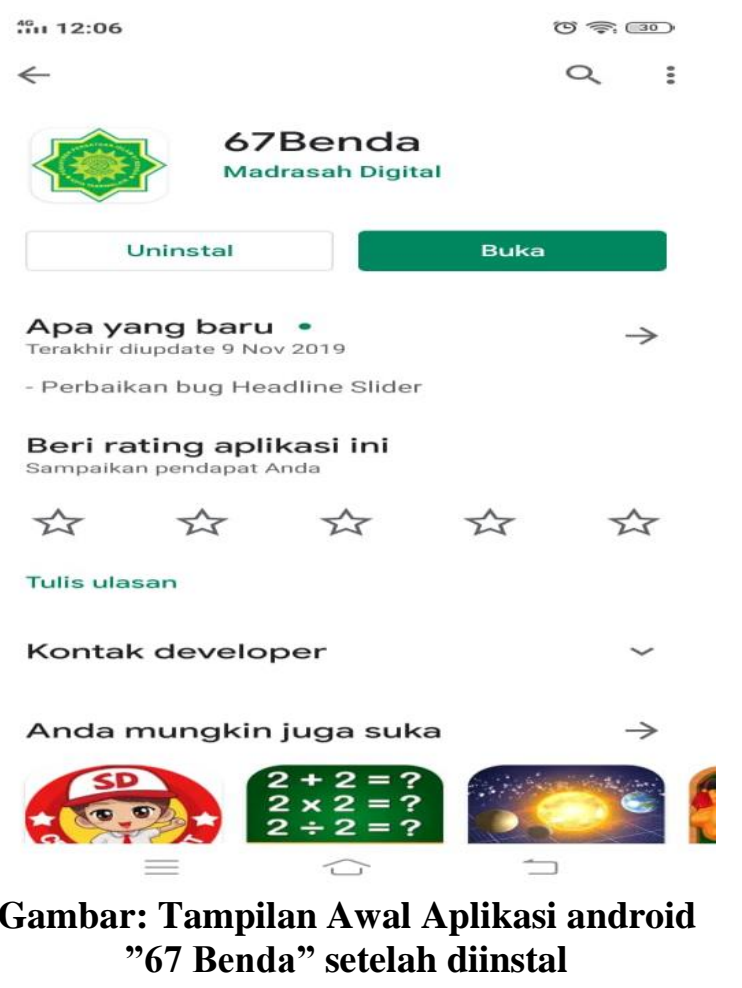

Upaya memberikan kualitas pelayanan terbaik kepada orang tua murid menjadi komitmen pihak lembaga. Pelayanan ini merupakan kegiatan sekolah baik secara langsung maupun tidak langsung untuk memenuhi kebutuhan pelanggan baik pelanggan internal maupun eksternal (Kompri, 2014). Pemberian layanan (melayani) keperluan orang atau masyarakat yang mempunyai kepentingan pada organisasi sesuai dengan aturan pokok dan tata cara yang telah ditetapkan oleh lembaga (Poltak, 2008). Sebagai proses yang baik untuk memberikan kepuasan kepada orang lain (orang tua murid) Pelayanan merupakan suatu kegiatan atau urutan kegiatan yang terjadi dalam interaksi langsung antar seorang dengan orang lain atau mesin secara fisik, dan menyediakan kepuasan pelanggan (Lukman, 2000).

Pelayanan sekolah atau lembaga pendidikan dapat dipahami sebagai suatu aktivitas atau serangkaian aktivitas lembaga pendidikan secara optimal untuk melayani keperluan orang tua murid yang mempunyai kepentingan pada sekolah dengan tata cara yang berlaku sesuai dengan keinginan dan harapan orang tua murid. Pelayanan yang cepat, akurat dan nyaman. Aplikasi android "^7 Benda" bertujuan untuk memberikan kemudahan orangtua sasntri dalam meliha perkembangan anaknya dan meemudahkan dalam berkomunikasi.

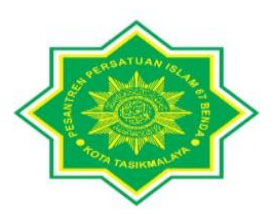

67Benda merupakan aplikasi berbasis Android yang dikembangkan untuk membantu para wali santri memantau aktivitas buah hatinya yang dititipkan di Pesantren Persatuan Islam 67 Benda Tasikmalaya

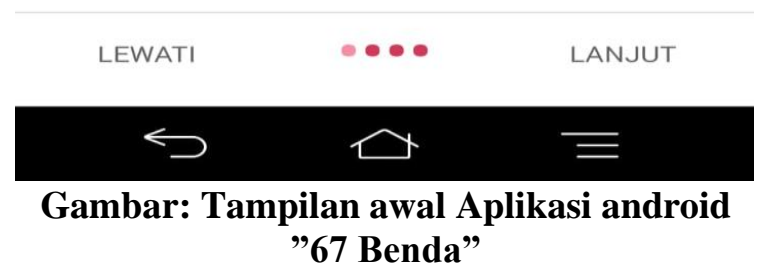

Menurut salah satu pendekatan kualitas pelayanan jasa yang banyak dijadikan acuan dalam riset pemasaran adalah model SERVQUAL (Service Quality) yang dikembang- kan oleh Zeithaml, Berry dan Parasuraman (A. Parasuraman, 2001) yaitu terdapat lima dimensi digunakan sebagai dasar 
skala mengukur kualitas pelayanan. Kelima dimensi kualitas pelayanan tersebut yaitu: (1) tangibles, meli- puti fasilitas fisik, perlengkapan, pegawai, dan sarana komunikasi; (2) realibility,yaitu kemampuan untuk memberikan pelayanan yang dijanjikan tepat waktu dan memuaskan;

responsiveness, kemam- puan para staf untuk membantu para pelanggan dan memberikan pelayanan yang tanggap; (4) assurance, mencakup kemampuan, kesopanan, bebas dari baha- ya resiko atau keraguan; (5) emphaty, yaitu mencakup kemudahan dalam mela- kukan hubungan komunikasi yang baik dan memahami kebutuhan para pelanggan (Hardiyansyah, 2011).

Tulisan ini mendeskripsikan hasil penelitian pada pelayanan pendidikan kepada orangtua murid dengan menggunakan aplikasi android. Untuk mengukur bagaimana kualaitas pelayanan diberikan, dilihat dari dimensidimensi kualitas pelayanan yang baik. Bagaimana dimensi tersebut dilaksanakan? Bagaimana kualitas pelayanan pendidikan kepada orangtua dicapai? Pertanyaan ini yang dijawab dalam penelitian ini.

\section{METODE PENELITIAN}

Penelitian ini menggunakan metode penelitian kualitatif dan bersifat deskriptif yang bertujuan mendeskripsikan dan menjelaskan suatu hal seperti kondisi apa adanya sesuai yang terjadi di lapangan dengan maksud mendapatkan gambaran mengenai sistem informasi manajemen berbasis aplikasi android "67 Benda" yang dipakai di pesantren PERSIS Benda kota Tasikmalaya dalam rangka meningkatkan pelayanan kepada wali santri.

Langkah-langkah yang ditempuh dalam rangka mendapatkan kelengkapan data dan informasi yang sesuai dengan fokus penelitian dilakukan beberapa teknik pengumpulan data yang dipergunakan yaitu: metode observasi ; metode wawancara; studi dokumentasi dan studi pustaka terkait dengan variabel penelitian.

Pengolahan dan analisis data dilakukan melalui proses penyederhanaan data ke dalam bentuk yang lebih mudah dibaca dan diinterpretasikan. Kemudian teknik analisa yang digunakan dalam penelitian ini adalah teknik analisa deskriptif dilakukan melalui tiga alur kegiatan, yaitu reduksi data; penyajian data; perivikasi dan membuat simpulan.

\section{HASIL PENELITIAN DAN PEMBAHASAN}

Berdasarkan rumusan masalah, ada tiga point penting yang peneliti dapatkan dalam penelitian yang sudah dilakukan, yaitu pertama, Kondisi pelayanan sekolah ; kedua Peranan aplikasi android "67 Benda" dalam pelayanan sekolah dan ketiga, peranan aplikasi android "67 Benda" dalam meningkatkan pelayanan sekolah kepada wali murid.

\section{Kondisi Pelayanan Sekolah}

Sistem yang berjalan di pesantren PERSIS Benda dalam memberikan layanan pendidikan sebelum menggunakan aplikasi android "67Benda" masih dilakukan secara manual, baik penyampaian informasi, proses pembayaran dan presensi. Akan tetapi dalam upaya memberikan informasi secara cepat, tepat dan akurat, pesantren membuat sebuah aplikasi sekolah yang berkualitas untuk menunjang percepatan penyebaran infor- masi. Berikut perbedaan secara nyata dalam penyampaian informasi secara analog dan secara digital dalam bentuk aplikasi android "67Benda" yang diterapkan di pesantren PERSIS Benda. 
Tabel 1. Perbedaan informasi analog VS informasi digital

\begin{tabular}{l|l}
\hline \multicolumn{1}{c|}{ Manual } & \multicolumn{1}{c}{ Aplikasi } \\
\hline $\begin{array}{l}\text { Informasi yang lama susah dicari } \\
\text { dan ditelusuri }\end{array}$ & $\begin{array}{l}\text { Mudah untuk dicari, ditelusuri, diakses dan digunakan sesuai dengan } \\
\text { kebutuhan pengguna }\end{array}$ \\
\hline Susah diperbaharui & $\begin{array}{l}\text { Mudah untuk diproduksi, dikirim, diterima, disaring, diperbaharui } \\
\text { berdasarkan kemampuan pengguna }\end{array}$ \\
\hline Format kaku dalam bentuk surat & Format penulisan dan isi pesan lebih bervariatif \\
\hline $\begin{array}{l}\text { Penyampaian informasi beragam } \\
\text { tergantung jarak dan waktu }\end{array}$ & $\begin{array}{l}\text { Tidak terhambat oleh jarak yang jauh, perbedaan bahasa dan } \\
\text { perbedaan waktu }\end{array}$ \\
\hline $\begin{array}{l}\text { Pengiriman dan penerimaan } \\
\text { informasi bisa lama }\end{array}$ & Pengiriman dan penerimaan informasi sangat cepat dan murah \\
\hline $\begin{array}{l}\text { Disimpan di tempat arsip yang } \\
\text { tercam pur dengan surat lainnya }\end{array}$ & $\begin{array}{l}\text { Mudah untuk disimpan dan diolah sehingga tidak memerlukan ruang } \\
\text { penyimpanan yang besar }\end{array}$ \\
\hline $\begin{array}{l}\text { Hanya terpaku pada bentuk analog } \\
\text { seperti surat dan mading sekolah }\end{array}$ & $\begin{array}{l}\text { Mudah diaplikasikan dalam berbagai media karena format isi dari } \\
\text { informasi digital akan sama, antara device yang satu dengan device } \\
\text { yang lainnya. }\end{array}$ \\
\hline
\end{tabular}

Sumber: Data Penelitian, 2020.

Tampilan data temuan pada tabel 1 di atas nampak bagaimana perbedaan pelayanan sekolah yang dilaksanakan secara manual dengan menggunakan aplikasi digital. Hadirnya aplikasi sangat membantu pada kemudahan dan kecepatan pelayanan sekolah kepada orangtua murid dan masyarakat. Dapat diambil contoh berikut terkait proses pembayaran SPP yang digunakan di pesantren PERSIS Benda sebelum diberlakukannya aplikasi android "67Benda" dilakukan secara manual. Dengan adanya aplikasi android diharap- kan pembayaran SPP dapat disajikan lebih efisien serta dapat menyimpan hasil yang telah diolah, dan juga untuk keamanan data lebih terjamin. Berikut perbedaan secara nyata dalam pembayaran SPP secara manual dan secara digital dalam bentuk aplikasi android "67Benda" yang diterapkan di pesantren PERSIS Benda

Tabel 2. Perbedaan pembayaran SPP secara manual VS Aplikasi

\begin{tabular}{l|l}
\hline \multicolumn{1}{c}{ Manual } & \multicolumn{1}{c}{ Aplikasi } \\
\hline Antrian pembayaran SPP panjang dan lama & \multicolumn{1}{c}{ Transaksi bisa dari mana saja dan kapanpun } \\
\hline $\begin{array}{l}\text { Membuat dan menghafalkan rumus-rumus } \\
\text { tertentu. }\end{array}$ & $\begin{array}{l}\text { Hanya perlu menginput data transaksi melalui } \\
\text { komputer. }\end{array}$ \\
\hline $\begin{array}{l}\text { Proses pembukuan harus dilakukan dengan } \\
\text { mencatat secara manual. }\end{array}$ & $\begin{array}{l}\text { Seluruh proses pembukuan dapat dilakukan secara } \\
\text { otomatis. }\end{array}$ \\
\hline $\begin{array}{l}\text { Membutuhkan waktu yang cukup lama untuk } \\
\text { menyelesaikan pembukuan. }\end{array}$ & $\begin{array}{l}\text { Proses pembukuan jauh lebih cepat sehingga dapat } \\
\text { menghemat waktu dan tenaga. }\end{array}$ \\
\hline Laporan keuangan harus dikerjakan secara manual. & $\begin{array}{l}\text { Laporan keuangan dapat disajikan secara otomatis dan } \\
\text { realtime. }\end{array}$ \\
\hline $\begin{array}{l}\text { Kerangka kerja akuntansi kurang efektif dan } \\
\text { efisien. }\end{array}$ & Kerangka kerja akuntansi lebih efisien. \\
\hline $\begin{array}{l}\text { Pencatatan utang dan piutang tidak terkelola } \\
\text { dengan baik. }\end{array}$ & $\begin{array}{l}\text { Manajemen utang dan piutang menjadi lebih baik } \\
\text { dengan fitur pengingat. }\end{array}$ \\
\hline $\begin{array}{l}\text { Rentan terjadinya kesalahan dalam mencatat data } \\
\text { transaksi dan perhitungan }\end{array}$ & $\begin{array}{l}\text { Meminimalisir terjadinya kesala han dalam } \\
\text { perhitungan. }\end{array}$ \\
\hline $\begin{array}{l}\text { Jika terjadi kesalahan, harus mengulang proses } \\
\text { dari awal }\end{array}$ & $\begin{array}{l}\text { Hanya perlu mengganti data yang salah, tanpa perlu } \\
\text { mengulang proses dari awal }\end{array}$ \\
\hline Sual
\end{tabular}

Sumber: Data Penelitian, 2020.

Proses presensi yang digunakan di pesantren PERSIS Benda sebelum diberla- kukannya aplikasi android "67Benda" dilakukan secara manual, tapi pesantren 
PERSIS Benda kota Tasikmalaya saat ini menerapkan aplikasi android "67Benda" untuk mempermudah penyampaian informasi absensi siswa kepada orang tua mereka dengan memanfaatkan teknologi informasi dan telekomunikasi yaitu ponsel berbasis android dimana aplikasi ini dapat menyampaikan absensi siswa kepada orangtua siswa setiap hari sehingga orang tua dapat melihat absensi anaknya di sekolah dan komunikasi antara sekolah dengan orang tua juga dapat terjalin dengan baik

Tabel 3. Perbandingan absensi manual dan Aplikasi

\begin{tabular}{|c|c|}
\hline Manual & Aplikasi \\
\hline $\begin{array}{l}\text { Absensi manual bisa diketahui ketika pembagian } \\
\text { rapor }\end{array}$ & Absensi langsung bisa dilihat setiap hari \\
\hline $\begin{array}{l}\text { Memakan biaya yang besar dalam jangka waktu } \\
\text { yang panjang }\end{array}$ & $\begin{array}{l}\text { Pengeluaran hanya besar di awal ketika pengadaan } \\
\text { aplikasi }\end{array}$ \\
\hline Akurasi data rendah & Akurasi data lebih tinggi \\
\hline Menyulitkan pemantauan siswa secara berkala & Memudahkan pemantauan semua pihak terkait \\
\hline Fitur terbatas hanya menampung data kehadiran & $\begin{array}{l}\text { Fitur bisa beragam dan terhubung dengan fitur } \\
\text { lainnya }\end{array}$ \\
\hline Tingkat keamanan rendah & Data presensi terjamin \\
\hline
\end{tabular}

Sumber: Data Penelitian, 2020.

Dalam upaya meningkatkan kepuasan murid dan orangtua murid, kualitas layanan merupakan faktor terpenting dalam proses peningkatan kualitas pendidikan . Terdapat lima dimensi pengukuran kualitas layanan pesantren PERSIS Benda Kota Tasikmalaya, yaitu : bukti fisik, kehandalan, daya tanggap, jaminan dan empati.Berikut deskripsi hasil temuan penelitian pada setiap aspek pelayanan yang diberikan sekolah.

\section{Bukti Fisik}

Bukti fisik yaitu kemampuan suatu perusahaan dalam menunjukkan eksistensi kepada pihak eksternal. Penampilan dan kemampuan sarana dan prasarana fisik perusahaan dan keadaan lingkungan sekitarnya adalah bukti nyata dari pelayanan yang diberikan oleh pemberi jasa (Lupiyoadi, 2006). Bukti fisik dari jasa adalah fasilitas dan peralatan fisik serta penampilan karyawan yang professional (Kotler, 2003)

Berdasarkan temuan penelitian, penerapan aplikasi android "67Benda" telah dilengkapi infrastruktur yang lengkap seperti, wifi sekolah, komputer / laptop dan ruangan IT yang lumayan nyaman. Dengan begitu, infrastruktur di pesantren PERSIS Benda Kota Tasikma laya dapat dikatakan baik secara keseluru- han sehingga mendukung terlaksananya penerapan aplikasi android "67Benda".

\section{Kehandalan}

Kehandalan adalah kemampuan perusahaan untuk memberikan pelayanan sesuai yang dijanjikan secara akurat dan terpercaya (Lupiyoadi, 2006). Penerapan aplikasi android "67Benda" sebagai salah satu bentuk pelayanan sekolah bertujuan untuk memudahkan wali santri dalam mendapatkan informasi. Bentuk kehandalan suatu aplikasi dapat diukur dari kesesuaian penerapan aplikasi dengan tujuan yang diinginkan.

Menurut wawancara berbagai pihak, pelaksanaan aplikasi android "67Benda" di pesantren PERSIS Benda kota Tasikmalaya sudah berjalan dengan baik walaupun masih harus ada perbaikan dan peningkatan layanan agar lebih bisa diandalkan sebagai media layanan sekolah. Berdasarkan hasil observasi, peneliti menemukan bahwa aplikasi sudah ada peningkatan tipe dan versi, awalnya tipe 14 versi 1.1.1 menjadi menjadi tipe 15 versi 1.1.2, dengan kata lain aplikasi versi sekarang lebih bagus dan lebih bisa dihandalkan. 


\section{Daya Tanggap}

Daya tanggap adalah suatu kemauan untuk membantu dan memberikan pelayanan yang cepat (responsif) dan tepat kepada pelanggan, dengan penyampaian informasi yang jelas. Membiarkan konsu- men menunggu tanpa adanya suatu alasan yang jelas menyebabkan persepsi yang negatif dalam kualitas pelayanan (Lupiyoadi, 2006). Dengan kata lain daya tanggap adalah keinginan para staf untuk membantu para pelanggan dan membe- rikan pelayanan dengan tanggap (Tjiptono, 2005). Daya tanggap berkai- tan dengan kesediaan dan kemampuan penyedia layanan untuk membantu para pelanggan dan merespon permintaan mereka dengan segera (Tjiptono, 2005).

Cara wali santri apabila mendapatkan kesalahan data dalam penerapan aplikasi biasanya langsung menghubungi nomor tata usaha dan bertanya langsung kepada petugas atau wali kelas yang telah ditunjuk oleh pesantren. Berdasarkan temuan penelitian, petugas dan semua pihak yang terkait dengan penerapan aplikasi android "67Benda" sudah berusaha cepat tanggap dalam memberi kan pelayanan untuk memenuhi keinginan dan kebutuhan pengguna. Dalam pelaksanaannya, diharapkan adanya fitur tanya jawab dalam aplikasi android "67Benda" ini sehingga apabila ada keluhan layanan, wali santri menjadi mudah untuk bertanya melalui aplikasi dan tidak perlu menggunakan media lain untuk menghubungi TU dan wali kelas.

\section{Jaminan}

Jaminan yaitu pengetahuan, kesopansantunan, dan kemampuan para pegawai perusahaan untuk menumbuhkan rasa percaya para pelanggan kepada perusa- haan (Lupiyoadi, 2006). Jaminan berarti bebas dari bahaya, risiko, atau keragu-raguan (Tjiptono, 2005). Setiap bentuk pelayanan memerlukan adanya kepastian atas pelayanan yang diberikan. Bentuk kepastian dari suatu pelayanan sangat ditentukan oleh jaminan dari pegawai yang memberikan pelayanan, sehingga orang yang menerima pelayanan merasa puas dan yakin bahwa segala bentuk urusan pelayanan yang dilakukan atas tuntas dan selesai sesuai dengan kecepatan, ketepatan, kemudahan, kelan- caran dan kualitas layanan yang diberikan (A. Parasuraman, 2001).

Jaminan yang diupayakan sekolah mengenai kemampuan pengetahuan terhadap produk pelayanan aplikasi android "67Benda" dan kemampuan dalam menanamkan kepercayaan pengguna terhadap sekolah, yaitu dengan memberikan satu password khusus bagi setiap pengguna dan petugas. Pengguna umum dapat langsung mengakses informasi dan pengumuman lainnya yang bersifat umum, adapun bagi orang tua atau wali santri, diberikan akses untuk sign up, login dan logout agar bisa mengakses informasi-informasi yang bersifat lebih khusus. Begitu juga hanya petugas yang mempunyai akses khusus dalam merubah dan menghapus informasi yang disampai kan dalam aplikasi android "67Benda" ini.

Berdasarkan observasi, pesantren juga telah menunjuk petugas IT yang bertitel sarjana komputer sehingga petugas yang diamanahi pesantren mengetahui seluk beluk penerapan aplikasi dan proses pengelolaan informasi sehingga aplikasi ini bisa berjalan sesuai dengan yang diharapkan dan direncanakan.

Berdasarkan temuan di atas, dapat disimpulkan bahwa aplikasi android "67Benda" dapat memberikan jaminan kepada pengguna berupa akses khusus bagi orang tua atau wali murid dan kemampuan petugas yang mumpuni dalam penerapan aplikasi.

\section{Empati}

Empati adalah memberikan perhatian yang tulus dan bersifat individual atau pribadi yang diberikan kepada para pe- langgan dengan berupaya memahami keinginan konsumen. Di mana suatu perusahaan diharapkan memiliki penger- tian dan pengetahuan tentang pelanggan, memahami kebutuhan pelanggan 
secara spesifik, serta memiliki waktu pengoperasian yang nyaman bagi pelanggan (Lupiyoadi, 2006). Empati berarti kemudahan dalam melakukan hubungan, komunikasi yang baik, perhatian pribadi, dan memahami kebutuhan para pelanggan (Tjiptono, 2005).

Dalam penerapan aplikasi android "67Benda", ada dua pihak yang bisa mengakses aplikasi yaitu admin dan pengguna. Aplikasi android "67Benda" bisa diakses semua pengguna dalam rangka mendapatkan informasi-informasi terkait informasi kegiatan dan pengu- muman pesantren yang bersifat umum. Berdasarkan temuan tersebut, aplikasi android "67Benda" terbukti memudahkan semua pihak mendapatkan informasi dari sekolah tanpa terkecuali. Setelah proses instalasi, pengguna bisa melihat pengu- muman dan berita dari pesantren, adapun akses diberikan kepada wali santri setelah melakukan proses registrasi dan berkoordinasi dengan petugas IT dan semua pengguna terlayani dengan baik.

\section{Aplikasi android "67 Benda" di pesantren PERSIS Benda kota Tasikmalaya}

Berikut ini akan dideskripsikan hasil penelitian yang diperoleh mengenai aplikasi android "67Benda" di pesantren PERSIS Benda kota Tasikmalaya. Dalam rangka untuk mengetahui kelebihan dan kekurangan aplikasi android "67Benda" di pesantren PERSIS Benda kota Tasikma- laya tentu diperlukan pengukuran kualitas aplikasi sebagai acuan untuk perbaikan ke depan.

Kepuasan pengguna merupakan salah satu tolak ukur keberhasilan penerapan sebuah sistem informasi. Pengguna yang merasa puas atas sebuah sistem informasi, maka kinerjanya dalam pengelolaan peru sahaan akan efektif dan efisien dalam pencapaian tujuan. pengukuran kualitas aplikasi meliputi waktu respon, akurasi data, kekinian data, kelengkapan, keanda lan dan kemudahan penggunaan.

\section{Waktu Respon}

Waktu respon suatu sistem informasi merupakan salah satu kualitas sistem informasi. Jika kecepatan akses sistem informasi cepat, maka sistem informasi tersebut memiliki kualitas yang baik. Berbicara tentang performa aplikasi tentu banyak hal yang harus diperhitungkan, salah satunya adalah waktu respon dari aplikasi tersebut. Permasalahan waktu respon yang lambat adalah permasalahan klasik yang dihadapi oleh pengembang aplikasi-aplikasi di dunia (Ridho, M.; Pinandito, 2018).

Aplikasi android "67Benda" dapat diakses di mana saja dan kapan saja. Hal ini memudahkan pengguna untuk mengakses kapanpun dan dimanapun untuk mendapatkan sebuah informasi tidak ada batas waktu untuk menghalanginya. Aplikasi android "67Benda" dapat diakses di mana saja dengan cepat dan tepat. Berdasarkan observasi, aplikasi android "67Benda" dapat diakses di mana saja dan kapan saja dengan gadget yang berbasis android kecuali ada kendala teknis seperti jaringan internet yang buruk karena cuaca atau tempat tinggal pengguna yang terletak di pedalaman.

\section{Akurasi Data}

Kualitas informasi pelayanan harus didukung oleh keakuratan informasi yang diberikan. Faktor keakuratan informasi merupakan salah satu hal yang paling penting dalam pelayanan dan penyam paian informasi. Informasi yang diberikan harus bebas dari kesalahan-kesalahan dan tidak bias atau menyesatkan. Informasi harus jelas mencerminkan maksudnya karena dari sumber informasi sampai ke penerima informasi kemungkinan banyak terjadi gangguan (noise) yang dapat merubah atau merusak informasi tersebut (Angkoso, S.; Rahmanto, 2017).

Salah satu indikator akurasi data adalah informasi yang disampaikan dalam aplikasi android "67Benda" merupakan informasi yang berasal dari sumber yang bisa dipercaya dan dipertanggungjawab kan. Berdasarkan 
observasi, informasi android "67Benda" adalah informasi yang akurat selalu berasal dari sumbernya yang bisa dipercaya dan dipertanggungjawab kan. Informasi absensi siswa berasal dari guru-guru mata pelajaran yang dilaporkan ke petugas piket dan data tersebut diberi kan kepada pengelola IT yang memasukan atau menginput data ke aplikasinya.

\section{Kekinian Data}

Informasi merupakan landasan di dalam pengambilan keputusan. Maka, informasi harus disajikan secara tepat waktu. Informasi yang sudah usang tidak akan mempunyai nilai lagi, karena bila pengambilan keputusan terlambat dapat berakibat fatal untuk organisasi. Kebutuhan akan tepat waktunya sebuah informasi itulah yang pada akhirnya akan menye- babkan mahalnya nilai suatu informasi (Angkoso, S.; Rahmanto, 2017).

Informasi yang disajikan aplikasi android "67Benda" selalu diusahakan update dan kekinian. Informasi yang ditampilkan sudah tepat pada waktunya ketika dibutuhkan oleh pengguna. Aplikasi android "67Benda" sangat membantu wali santri dalam mendapatkan informasi yang fresh yang tepat pada saat dibutuhkan, yakni informasi absensi siswa untuk melihat perkembangan belajar anak didiknya sehingga setiap hari wali santri. Berdasarkan observasi, peneliti menemu- kan bahwa absensi santri setiap hari disetorkan oleh petugas piket kepada petugas IT untuk diinput setiap harinya.

Berdasarkan temuan penelitian, dapat disimpulkan informasi yang disampaikan berupa presensi sudah up to date sedang kan informasi dalam bentuk informasi tentang kegiatan yang diadakan pesantren belum benarbenar update dan kekinian.

\section{Kelengkapan}

Kelengkapan dari kualitas informasi adalah kelengkapan isi dari informasi yang dihasilkan oleh sistem informasi. Informasi yang lengkap adalah informasi yang mencakup 30 seluruh informasi yang dibutuhkan oleh pengguna sistem informasi tersebut. Aplikasi android "67Benda" seharusnya menyajikan infor- masi yang lengkap untuk memenuhi kebu tuhan guru dan wali santri. Kelengkapan yang dimaksud bisa diartikan lengkapnya informasi yang disajikan atau lengkapnya fitur yang disediakan aplikasi.

Berdasarkan observasi, ada tiga kategori fitur dari aplikasi android "67Benda" yang disediakan di pesantren PERSIS Benda Kota Tasikmalaya yaitu pengumuman, presensi dan pembaya- ran.Walaupun untuk sementara sudah dirasa cukup, tapi aplikasi harus terus dikembangkan dan menyesuaikan kebutu- han pengguna serta pesantren. Aplikasi android "67Benda" dalam perkembangan nya harus disesuaikan dengan kebutuhan kondisi sekarang sehingga dalam penera pannya bisa ditambahkan fitur yang lebih menarik dan sesuai dengan perkembangan zaman.

\section{Keandalan}

Keandalan sistem dalam hal ini adalah ketahanan sistem informasi dari kerusakan dan kesalahan. Keandalan sistem in- formasi dapat juga dilihat dari mampu atau tidaknya sistem informasi untuk melayani kebutuhan pengguna sesuai dengan tujuan yang sudah direncanakan.

Aplikasi android "67Benda" merupa-

kan terobosan baru pesantren dalam meningkatkan layanan sekolah kepada wali santri sesuai dengan tuntutan zaman dengan memanfaatkan kecanggihan tekno- logi yang ada. Aplikasi android "67Benda" membantu wali santri dalam mendapatkan informasi yang dikeluarkan oleh pesantren, wali santri tinggal buka aplikasi langsung tahu info kegiatan dan lainnya.

Berdasarkan temuan di atas nampak bahwa aplikasi ini ternyata bisa dihandalkan dalam mendapat informasi dan sangat berpotensi menam- bah kualitas layanan sekolah apabila dikelola dengan sebaikbaiknya. 


\section{Kemudahan Penggunaan}

'Sistem informasi dapat dikatakan berkualitas jika sistem tersebut dirancang untuk memenuhi kepuasan pengguna, salah satunya melalui kemudahan dalam penggunaan sistem dan kemudahan men-dapatkan informasi. Kualitas sistem informasi didefinisikan sebagai perceived ease of use yang merupakan seberapa besar teknologi komputer dirasakan relatif mudah untuk dipahami dan digunakan (Utami, 2009).

Berdasarkan berbagai penuturan aplikasi android "67Benda" sangat mudah dan simple sehingga memudahkan pengguna dalam menjalankan aplikasi. Aplikasi ini mudah dipelajari, mudah dipahami dan tidak memerlukan waktu yang lama dalam mempelajarinya sehingga mudah untuk dijalankan. Berdasarkan observasi, aplikasi android "67Benda" sangat mudah untuk digunakan dari mulai tahapan install sampai tahap mendapat informasi yang disediakan.

Berdasarkan hasil temuan di atas, disimpulkan bahwa aplikasi android "67Benda" merupakan aplikasi yang mudah digunakan dan cepat dimengerti oleh penggunanya. Mereka tidak menga- lami kesusahan dalam menjalankan aplikasi sehingga menjadi lebih tertarik menggunakan aplikasi tersebut.

Peranan aplikasi android "67Benda" dalam meningkatkan pelayanan sekolah kepada wali murid

\section{Peranan Aplikasi}

Penerapan aplikasi android "67Benda" walaupun pada intinya adalah mening-katkan pelayanan sekolah kepada wali santri di pesantren PERSIS Benda Kota Tasikmalaya, akan tetapi secara tidak langsung berperan juga kepada berbagai pihak yang berkaitan dengan proses pelayanan. Aplikasi android "67Benda" dilihat dari segi peranannya terbagi menjadi dua, internal dan eksternal. Pihak internal adalah dewan guru dan pihak eksternal adalah wali santri.
Peranan internal, yaitu peranan aplikasi android yang terasa bagi dewan guru adalah membantu para guru dalam memberikan informasi kepada wali santri tentang absensi kehadiran santri sehingga dengan laporan harian yang ada di aplikasi, wali santri bisa mengontrol kehadiran anaknya sehari-hari. Berdasarkan temuan penelitian, aplikasi android "67Benda" dirasakan berperan dalam pengendalian operasional sekolah sebagai sarana wali santri menda- patkan informasi dari pesantren. Dalam prakteknya, aplikasi ini sebagai sarana penghubung informasi dan komunikasi antara pesantren dan guru dengan wali santri sehingga peranannya sangat penting untuk dikelola dengan baik.

Peranan eksternal, yaitu aplikasi android "67Benda" berperan secara nyata dalam layanan sekolah, wali santri menjadi lebih mudah untuk mencari informasi yang berkaitan dengan pesantren. Penerapan aplikasi android "67Benda" membuat wali santri dapat mengetahui kehadiran santri secara lang- sung sehingga lebih cepat berkoordinasi apabila anaknya tidak masuk sekolah. Berdasarkan temuan penelitian, aplikasi android "67Benda sangat berpengaruh terhadap layanan karena mempermudah wali santri dalam mendapatkan informasi dari pesantren.

\section{Faktor Pendukung Pererapan Aplikasi}

Berdasarkan temuan penelitian, faktor pendukung penerapan aplikasi ini terbagi menjadi dua faktor, yaitu :

Pertama : Faktor internal berasal dari komitmen pimpinan pesantren yang tinggi dalam meningkatkan manajemen pelaya- nan sekolah dengan membentuk tim IT yang cukup dari segi jumlah petugas dan mumpuni dalam penerapan aplikasi dan infrastruktur yang memadai disertai dengan dukungan dari dewan guru yang tinggi.

Kedua : Faktor eksternal berasal dari dukungan wali santri dan antusiasme yang tinggi dalam mewujudkan program sekolah. 


\section{Faktor Penghambat Penerapan Aplikasi}

Selain faktor pendukung, penerapan aplikasi android "67Benda" di pesantren PERSIS Benda Kota Tasikmalaya tidak terlepas dari adanya hambatan-hambatan yang merintangi pelaksanaan program sekolah.

Berdasarkan temuan penelitian, faktor penghambat penerapan aplikasi ini terbagi menjadi dua faktor, yaitu :

Pertama : Faktor internal berasal dari sumber daya manusia yang berpengaruh kepada pengelolaan aplikasi yang belum optimal dan keterbatasan aplikasi yang masih terbatas pada gadget yang berbasis android sehingga belum bisa digunakan pada gadget yang berbasis IOS.

Kedua : Faktor eksternal aplikasi sudah diakses karena jaringan internet dan sinyal buruk berdasarkan cuaca atau letak geografis wali santri.

\section{SIMPULAN}

Pelayanan sekolah di pesantren PERSIS Benda kota Tasikmalaya telah beralih dari pelayanan secara manual menjadi pelayanan digital dengan diterapkannya aplikasi "67Benda" di pesantren. Pelayanan digital tersebut meliputi pelayanan penyampaian informasi dan kegia- tan, pembayaran SPP dan presensi. Fitur baru bisa bertambah seiring waktu sesuai dengan kebutuhan pesantren dan perkembangan zaman.

Aplikasi android "67Benda" di pesantren PERSIS Benda kota Tasikmalaya dalam penerapannya sudah berjalan dengan baik. Aplikasi android menjadi satu sarana penghubung antara pesantren dan wali santri, walaupun harus terus diperbaiki dan dioptimalkan sehingga menjadi aplikasi yang bisa diandalkan.

Peranan aplikasi android "67Benda" sangat berpengaruh dalam meningkatkan pelayanan sekolah kepada wali santri karena mempermudah wali santri dalam mendapatkan informasi dari pesan- tren, membantu wali santri dalam mengetahui total tunggakan santri dan bisa memantau kehadiran anaknya secara langsung di aplikasi tanpa harus bertanya terlebih dahulu ke wali kelas.

\section{DAFTAR PUSTAKA}

A. Parasuraman. (2001). The Behaviorial Consequenses of Service Quality. Journal of Marketing, 60, 69.

Al Rekhawi, H. A. (2020). Android Applications Development Intelligent Tutoring System. International Journal of Academic Information Systems Research (IJAISR), 4(5), 33-58.

Angkoso, S.; Rahmanto, A. N. . Y. S. (2017). Faktor-faktor yang mempengaruhi kualitas informasi pelayanan bidang akademik kepada mahasiswa. Jurnal Manajemen Komunikasi, 1(2), 234264.

Hardiyansyah. (2011). Kualitas Pelayanan Pendidikan. Gava Media.

Hariyanto, A. (2019). Aplikasi Mobile Sistem Informasi Akademik Labschool Universitas Negeri Semarang Berbasis Android. UNNES Journal of Mathematics, 8(1), 12.

Hutagalung, M. A. K. (2019). Pengaruh Kualitas Pelayanan Dan Bagi Hasil Terhadap Minat Masyarakat Menjadi Nasabah Bank Syari'ah. Jurnal Al-Qasd Islamic Economic Alternative, 1(2), 228-239.

Juansyah, A. (2015). Pembangunan Aplikasi Child Tracker Berbasis Assisted-Global Positioning System dengan Platform Android. Jurnal Ilmiah Komputer Dan Informatika, 1(1), 11-19.

Kompri. (2014). Manajemen Sekolah Teori dan Praktek. Alfabeta.

Komputer, W. (2013). Membuat Aplikasi Android Tanpa Coding dengan APP Inventor. PT. Gramedia. 
Kotler, P. (2003). Manajemen Pemasaran. Indeks kelompok Gramedia.

Kuswanto, J. . F. R. (2018). Media Pembelajaran Berbasis Android Pada Mata Pelajaran Sistem Operasi Jaringan Kelas XI. Jurnal Media Infotama, 14(1), 14-20.

Lukman, S. (2000). Pengembangan Pelaksanaan Pelayanan Prima. LAN.

Lupiyoadi, H. (2006). Manajemen Pemasaran Jasa. Salemba Empat.

Mustakini, J. (2007). Model Kesuk sesan Sistem Teknologi Informasi. Andi.

Poltak, L. (2008). Reformasi Pelayanan Publik. Bumi Aksara.

Putra, D. R. . M. A. N. (2016). Pengembangan Game Edukatif Berbasis Android Sebagai Media Pembelajaran Akuntansi Pada Materi Jurnal Penyesuaian Perusahan Jasa. Jurnal Pendidikan Akuntansi Indonesia, 4(1), 28.
Ridho, M.; Pinandito, A. . R. K. D. (2018). Perbandingan Performa Progressive Web Apps dan Mobile Web Terkait Waktu Respon, Penggunaan Memori dan Penggunaan Media Penyimpanan. Jurnal Pengembangan Teknologi Informasi Dan Ilmu Komputer, 2(10), 3483-3491.

Rusdiana, A. (2015). Pengelolaan Pendidikan. Pustaka Setia.

Tjiptono, F. (2005). Strategi Pemasaran (Jogjakarta). Andi.

Utami, I. . (2009). Pengaruh Kepuasan Pengguna Sistem Informasi terhadap kinerja individu. Jurnal SNA, 12, 1-47.

Xiao, J.; Chen, S.; He, Q.; Feng, Z. . X. X. (2020). An Android application risk evaluation framework based on minimum permission set identification. Journal of Systems and Software, 1-43. 